\title{
The Role of Corporate Governance as a Leverage Moderating and Free Cash Flow on Earnings Management
}

\author{
Reni Yendrawati, Erin Febriana Asy'ari \\ Department of Accounting Faculty of Economics Universitas Islam Indonesia \\ Jl. Ringroad Utara, Condong Catur, Sleman, Yogyakarta, 55283, Indonesia
}

\author{
Keywords: \\ Leverage, Free \\ Cash Flow, \\ Earnings \\ Management, \\ Corporate Gover- \\ nance, Managerial \\ Ownership, \\ Institutional \\ Ownership, \\ Independent \\ Commissioner, \\ Audit Committee \\ JEL Classification: \\ G34, G31
}

Kata Kunci:
Leverage, Free Cash
Flow, Manajemen
Laba, Corporate
Governance,
Kepemilikan
Manajerial,
Kepemilikan
Institusional,
Komisaris
Independen, Komite
Audit

\begin{abstract}
According to agency theory there were separation of function between principal and agent. This separation created different interest between principal and agent. This condition occurs because of the asymmetric information that agent more knew company information than principal. Therefore, it was interesting to study the actions of management. This research aimed to analyze the influence of leverage and free cash flow to earning management and the ability to analyze the influence corporate governance consisting of managerial ownership, institusional ownership, independent commissioner, and audit comittee in influencing earnings management on the listed manufacturing companies in Indonesia Stock Exchange during years 2010-2014. The results showed that leverage significantly influence to earnings management and free cash flow significantly influence to earnings management moderating variables that influence the relationship of leverage to earnings management is managerial ownership, independent commissioner, audit comitte, and moderating variables that influence the relationship of free cash flow to earning management was managerial ownership and institusional ownership.
\end{abstract}

\begin{abstract}
ABSTRAK
Menurut teori keagenan terdapat pemisahan fungsi antara principal dengan agen. Pemisahan fungsi ini menciptakan kepentingan yang berbeda antara principal dengan agen. Hal ini terjadi karena adanya informasi asimetris, dimana agen lebih mengetahui informasi perusahaan dibanding dengan prinsipal. Oleh karena itu menarik untuk mempelajari tindakan manajemen. Penelitian ini bertujuan untuk menganalisis pengaruh leverage dan free cash flow terhadap manajemen laba dan kemampuan corporate governance yang terdiri dari kepemilikan manajerial, kepemilikan institusional, komisaris independen, dan komite audit dalam mempengaruhi manajemen laba pada perusahaan manufaktur yang terdaftar di Bursa Efek Indonesia selama tahun 2010-2014. Hasil penelitian ini menunjukkan bahwa leverage dan free cash flow berpengaruh secara signifikan terhadap manajemen laba. Kepemilikan manajerial, komisaris independen, dan komite audit adalah variabel yang memoderasi hubungan leverage dengan manajemen laba. Kepemilikan manajerial dan kepemilikan institusional adalah variabel yang memoderasi hubungan free cash flow dengan manajemen laba.
\end{abstract}


Earnings management is the action taken by the management company to affect reported earnings, which could provide information about the economic benefits (economic advantage) who was not experienced by the company, and in the long term such actions could be detrimental to the company (Naftalia, 2013). This is also possible because management has the opportunity, power, and knowledge to adjust how much profit is desired.

Many related groups have an interest in the financial statements and each of them has different interests. The interest group are manager, owner, investor, creditor, or other groups. Each put different expectations on the financial statements. So there is a conflict of interest caused by information asymmetry between the principal and the agent. Conflicts of interest between the manager as agent and owner as principal are discussed in agency theory.

Agency theory illustrates that earnings management occurs as a result of the different economic interests between the management as an agent and as principal owner (Gunawan, Darmawan, \& Purnamawati, 2015). Information that managers have not always similar to that held by the shareholders, where managers know the actual condition of the company, the differences information about this company called information asymmetry, where the company manager uses his knowledge for the benefit of himself.

Based on agency theory, management actions can be overcome or minimized through corporate governance mechanisms. The mechanism of corporate governance is proposed concept for improving corporate performance through supervision or monitoring management performance and ensure the accountability of management to the stakeholders by looking at the regulatory framework (Naftalia, 2013). There are 4 of corporate governance mechanism that can control the actions of earnings management, the managerial ownership, institutional ownership, independent board, and audit committee.
Managerial ownership, which has a share ownership by the management of the company where the existence of managerial ownership, management not only functioned as a manager of the company but also as a shareholder. Then there is the institutional ownership, according to Ridwan \& Gunardi (2013) institutional investor ownership can use the periodic information in predicting future earnings compared to non-institutional investors. Then an independent board of commissioners, an independent board of commissioners is a member of the board of commissioners who is not affiliated with the management of the company and any other member of the board of commissioners, and the controlling shareholder. And free from the business relationship or other relationship which could affect its ability to act independently (Fanani, 2014). Last is the audit committee, the audit committee's task is related to the quality of the financial reports, because of the audit committee is expected to assist the commissioners in performing the reports is controling the financial reporting process by management (Kristiani, Sulindawati, \& Herawati, 2014).

Leverage is indicated to be one of the causes of earnings management. According to Pambudi \& Sumantri (2014) an agreement between the company's debt as the debtor by creditors. In this debt agreements, there are the interests of the company to be assessed positively by the lenders in terms of ability to pay its debts. There is a possibility that the contract agreements trigger debt try to increase profits with the aim of showing the positive performance on creditors so as to obtain a booster of funds. Leverage can show how big the company's assets are financed by debt. Leverage measured by the ratio of total debt to total assets.

Companies with free cash flow is high will have a greater opportunity to earnings management, because the company indicated face greater agency problems (Agustia, 2013). Free cash flow is the free cash flow after investing company which 


\section{Jurnal Keuangan dan Perbankan | KEUANGAN}

Vol. 21, No. 3, Juli 2017: 412- 424

is expected to generate profits in the future, and has paid the debt, and has distributed dividends, but still have the rest of the cash. Free cash flow provides an overview of the company's ability in the future. In the other side of the free cash flow turned out to cause trouble the agency, which led to the management considered to be more selfish in using surplus cash. Thus, companies with high free cash flow will have a greater opportunity to earnings management, because the company indicated greater agency problems. The purpose of this study is to analyze the effect of leverage, free cash flow to earnings management as well as analyze the influence of corporate governance on leverage and free cash flow relationship with earnings management.

\section{HYPOTHESES DEVELOPMENT}

\section{The Effect of Leverage on Earnings Management}

Zakaria, Sanusi, \& Mohamed (2015) explains that the company has a high leverage may face the risk of bankruptcy if they are unable to make payments on their external debt financing. Therefore, usually a company that tends to have a high leverage will increase the level of such opportunistic earnings management to maintain its performance in the supervise of shareholders and the public. The level of corporate debt (leverage) could affect earnings management action. High leverage due to mismanagement in managing corporate finance or strategy implementation is lacking. Because of the lack of supervision led to high leverage, also will increase the acts oppurtunistic such as earnings management to maintain its performance in the eyes of shareholders and public (Naftalia, 2013). Leverage used in this study is the ratio between debt and assets. The greater the debt of a company compared to its assets, the greater the risk faced by the company to pay its obligations will be. The greater the leverage ratio shows the greater the company's dependence on external parties (creditors) and the greater the burden of debt costs (interest costs) that have to be paid by the company.

This is according to research conducted by Zamri, Rahman, \& Isa (2013) and conducted by Lee (2013) who found results that leverage positive effect on earning management action. Based on the description, first hypotheses of this research is:

$\mathrm{H}_{1}$ : leverage positive effect on earnings management

\section{The Effect of Free Cash Flow on Earnings Management}

Free cash flow can be interpreted as the existance of excess funds, which should be distributed to the shareholders but the decision was influenced by management policy (Fanani, 2014). Companies with free cash flow is high will have a greater opportunity to earnings management, because the company indicated face greater agency problems where the shareholder (principal) authorizes the management (agent). Agents are more aware of information about the state of the company including the existence of free cash flow. The transfer of responsibilities and power of shareholders to the manager, the agency raises issues related to the difference of interests between the shareholders or principal to his agent. The shareholders want the free cash flow distributed as dividends, while the manager wants free cash flow used for investments that will be profitable for the manager. Free cash flow contained in the company would affect the company's performance. Free cash flow can be interpreted as the existance of excess funds, which should be distributed to the shareholders but the decision was influenced by management policy (Arieska \& Gunawan, 2011).

The manager is always willing to improve power through control over resources are greater, 
it will continue to encourage managers to invest in an effort to expand the company and increase their incentives. Therefore, with the free cash flow will encourage managers to invest. As a result, companies with high free cash flow coupled with low growth opportunities will continue to tend to invest in projects with negative NPV, which may benefit managers, either in money or in return, but will degrade the company's performance. Furthermore, in a try to cover up the company's performance, the manager will act earnings management to increase profits (Fanani, 2014). So, it can be concluded that the higher the value of the surplus free cash flow of a company, the higher the possibility of earning management management. This is consistent with the results of research that has been done by Kono (2013) who found results that free cash flow positive effect on earnings management action. Based on the description, second hypotheses of this research is:

$\mathrm{H}_{2}$ : free cash flow positive effect on earnings management

\section{The Effect of Managerial Ownership on the Relationship between Leverage and Management}

Managerial ownership is share owned by management in person or share owned by subsidiaries of the concerned companies and affiliates. Indicators to measure the managerial ownership is the percentage ratio of the number of shares owned by the management of the entire outstanding share capital of the company (Agustia, 2013). With the managerial ownership that can be used to minimize earnings management due to the use of leverage by a management company for their managerial ownership can be aligning interests between shareholders and managers, where managers also act as shareholders. Based on the description, third hypotheses of this research is:
$\mathrm{H}_{3}$ : managerial ownership affects the relationship between leverage and earnings management

\section{The Effect of Managerial Ownership on the Relationship between Free Cash Flow and Earnings Management}

Managerial ownership is the ownership of a company's share by the management. With managerial ownership, management not only functions as a company manager but also as a shareholder. Management ownership of the shares of companies seen to align the potential difference between the interests of shareholders with management (Naftalia, 2013). So, the agency problems arising from their free cash flow of a company is assumed to be lost when a manager acts as well as an owner. From the standpoint of accounting theory, earnings management is largely determined by the motivation of corporate managers. Different motivation will produce a different amount of earnings management, such as the manager who also serves as a shareholder and a manager who is not a shareholder. Thus, fourth hypotheses can be developed as follows:

$\mathrm{H}_{4}$ : managerial ownership affects the relationship between free cash flow and earnings management

\section{The Effect of Institutional Ownership on the Relationship between Leverage and Earnings Management}

The institutional ownership is the ownership of the company's shares by an outsider in the form of an institution, which is expected to reduce the company's deviant management action. With the high institutional ownership, institutional investors will get a chance the company's control. Naftalia (2013) shortly explain that the high insti- 
tutional ownership limit managers to manage profit (earnings management). So, with the institutional ownership can help monitor outcomes measure enterprise managers in conducting related opportunistic action in leverage the company so as to minimize earnings management action. Thus, fifth hypotheses can be developed as follows:

$\mathrm{H}_{5}$ : institutional ownership affects the leverage relationships and earnings management

\section{The Effect of Institutional Ownership on the Relationship between Free Cash Flow and Earnings Management}

Free Cash Flow is the actual cash flows are distributed to investors after the company do all the investment and working capital required to maintain existance of operations (Agustia, 2013). Institutional ownership is the ownership of company shares by large investors such as insurance companies, banks, pension funds, and investment banking who buy shares in large quantities (Agustia, 2013). Institutional ownership is measured by the number of shares held by institutional investors compared to the total shares of the company. So that with the institutional parties who invest in the company can come to control the company's manager in the use of free cash flow. Thus, sixth hypotheses can be developed as follows:

$\mathrm{H}_{6}$ : institutional ownership affects the relationship of free cash flow and earnings management

\section{The Effect of Independent Directors on the Relationship between Leverage and Earnings Management}

Independent board task is to supervise and advise the board of directors, and ensures that the company has undertaken the responsibility to stakeholders. Independent Commissioners aim to balance in decision making especially in the framework of the protection of minority shareholders and other parties concerned. Research from Naftalia (2013) states that companies that have a composition of board members who come from outside the company can minimize profit management action. Thus, an independent board of commissioners can assist in making decisions within the company so as to protect shareholders from certain actions taken by management such as profit management actions caused by leverage. Thus, seventh hypotheses can be developed as follows:

$\mathrm{H}_{7}$ : independent directors of the board affect the relationship between leverage and earnings management

\section{The Effect of Independent Director on the Relationship between Free Cash Flow and Earnings Management}

Independent board includes a duty and responsibility to ensure that the company has effective business strategy (monitoring schedule, budget, and the effectiveness of the strategy), comply with the laws and regulations in force, and ensure that the principles and practices of good corporate governance has been complied with and implemented well (Agustia, 2013). So, with the independent board is expected to help minimize the actions of management in managing profit due to the fund company's free cash flow that is not handled properly by the management company for its own sake. Thus, eight hypotheses could be summarized is:

$\mathrm{H}_{8}$ : council independent commissioners effect on the relationship between free cash flow and earnings management 


\section{The Effect of the Audit Committee on the Relationship between Leverage and Earnings Management}

In accordance with Kep.29/PM/2004, the audit committee is a committee established by the board of directors to perform supervisory tasks management companies (Kristiani, Sulindawati, \& Herawati, 2014). The existence of the audit committee is very important for the management of the company. So, with the existence of audit committee in a company aim to balance in decision making especially in the framework of protection against minority shareholders and other parties related from earnings management action. If a company threatened liquidation which caused greater the leverage ratio shows the greater the company's dependence on external parties (creditors) and the greater the burden of debt costs (interest costs) to be paid by the company.

By increasing the leverage ratio (where the debt burden is also getting bigger) then it will affect the profitability obtained by the company, as most are used to pay interest on the loan, then the decision that tends to do with the immediate management is earnings management. By doing earnings management, the company's performance will look good in the eyes of shareholders and the public in spite of its imperiled liquidated. With the audit committee where audit committee was formed for the protection of the decision-making that will impact shareholders, is expected to oversee and protect shareholders from management actions related earnings leverage. Thus, ninth hypotheses can be developed as follows:

$\mathrm{H}_{9}$ : the audit committee has an effect on the relationship between leverage and earnings management

\section{The Effect of the Audit Committee on the Relationship between Free Cash Flow and Earnings Management}

The task of the committee dealing with the quality of the financial statements, because of the audit committee is expected to assist the commissioners in performing the tasks is overseeing the financial reporting process by management where the management often take action malakukan profit management company where management is given authority to the financial statements. The principal gives the authority to the management (agent). Agents are more aware of information about the state of the company including the existence of free cash flow. The transfer of responsibilities and powers of shareholders to the manager, the agency raises issues related to the difference of interests between the shareholders or principal by the agent (manager).

According to Statement of Financial Accounting Standard No. 2 Paragraph 05 (IAI, 2007), cash flow is defined as inflows and outflows of cash or cash equivalents. Cash flow statement classifies transactions into 3 activities, namely operating, financing, and investment. Cash flow problems indicated by the use of free cash flow. The shareholders want the free cash flow distributed as dividends, while the manager wants free cash flow used for investments that will be profitable for the manager. Free cash flow contained in the company would affect the company's performance. Free cash flow can be interpreted as the existance of excess funds, which should be distributed to the shareholders but the decision was influenced by management policy (Arieska \& Gunawan, 2011). Thus, tenth hypotheses can be developed as follows: 


\section{Jurnal Keuangan dan Perbankan | KEUANGAN}

Vol. 21, No. 3, Juli 2017: 412- 424

$\mathrm{H}_{10}$ : the audit committee has an effect on the relationship between free cash flow and earnings management

\section{METHODS}

The population of this study are all manufacturing companies listed on the Indonesia Stock Exchange. Samples are chosen based on purposive sampling method that is the determination of the sample based on the suitability of certain characteristics and criteria. The criteria used in sampling are as follows: (1) manufacturing companies listed on BEI 2010-2014; and (2) companies that have the required data. The number of samples meeting the criteria in this study were 175 companies.

Earnings management is proxied by discretionary accruals using the modified Jones model Dechow, Sloan, \& Sweeney (1995). The independent variable in this study is the use of leverage ratio that indicates the amount of debt used to finance the company's assets. Calculation of leverage is calculated as total debt divided by total assets. Free cash flow, this variable is calculated using the formula Brigham \& Houston (2010), namely:

Free Cash Flow=

NOPAT - Net Investment in Operating Capital

Note:

NOPAT $($ Net Operating Profit After Tax $)=$

EBIT (1-tax rate)

Net investment in operating capital $=$

total operational capital - total operational capital -1

Total operating capital $=$

net working capital operating + net fixed assets

Net working capital $=$

expedite assets - current liabilities without interest
Moderating variable in this research that corporate governance mechanism that consists of managerial ownership, institutional ownership, independent board, and audit committee. In this research, the researchers conducted several tests to process the data already obtained, namely descriptive analysis, classic assumption test consisting of normality test, multicolinearity test, autocorrelation test, heteroscedicity test. While testing the hypothesis there are F-test, t-test, the coefficient of determination, and multiple linear regression tests. Here is the regression equation used in this study:

$$
\begin{aligned}
\mathrm{DA}= & \alpha_{0}+\alpha_{1} \text { Lev }+\alpha_{2} \text { FCF }+\alpha_{3} \mathrm{KM}+\alpha_{4} \text { KepIns }+ \\
& \alpha_{5} \text { DKI }+\alpha_{6} \text { KA }+\alpha_{7} \text { Lev }^{*} \mathrm{KM}+\alpha_{8} \text { Lev }^{*} \\
& \text { KepIns }+\alpha_{9} \text { Lev }^{*} \mathrm{DKI}+\alpha_{10} \mathrm{Lev}^{*} \mathrm{KA}+\alpha_{11} \\
& \mathrm{FCF}^{*} \mathrm{KM}+\alpha_{12} \mathrm{FCF}^{*} \text { KepIns }+\alpha_{13} \mathrm{FCF}^{*} \mathrm{DKI}+ \\
& \alpha_{14} \mathrm{FCF}^{*} \mathrm{KA}
\end{aligned}
$$

Note:

Lev $\quad=$ level of corporate debt

$\alpha_{0} \quad=$ constants

$\alpha_{1-14}=$ coefficient

DA = earnings management proxy for discretionary accruals (DA)

KepIns = institutional ownership is measured by percentage share ownership owned by the institution

$\mathrm{KM}=$ managerial ownership is measured by the percentage of share owned by managerial

$\mathrm{KA}=$ audit committee is measured by the number of audit committee members present in the company

DKI = independent board of commissioners is measured by the percentage of independent commissioners compared to the total existing board of commissioners 


\section{RESULTS}

\section{Descriptive Analysis}

Based on Table 1 then the average of earning management (DA) has a positive value, this means that the companies sampled in the research actions earnings management by increasing profits, either by raising revenues or reduce the load. The average leverage (Lev) unfavorable because it exceeds the standard limit the use of leverage by $(0.5)$, while the data storage Free Cash Flow (FCF) is quite low. The average value of Managerial Ownership (KM) away from the fairly standard deviation thus Managerial Ownership data storage $(\mathrm{KM})$ is quite high. According Agustia (2013) from the descriptive statistics it is seen that the company's managerial ownership in Indonesia is very small with an average of less than 5 percent. So managers who also own shares of the company tend to take the policy to manage earnings from the point of view of the desire of investors, for example by increasing the reported profit so that many investors who are interested to invest and can raise the company's stock pLee.

The average value of Ownership instuonal (KepsIns) away from the standard deviation thus instuonal Ownership data storage (KepsIns) tall. The average value of an Independent Commissioner Board (DKI) approaching the standard deviation thus data storage Independent Commissioner Board Composition (DKI) is low. The average value of the Audit Committee (AC) approached the standard deviation value, thus the data storage $A C$ is low. It also indicates that the data on the audit committee variables have the same distribution with a mean value -rata of the audit committee which has one of the audit committee.

\section{Classic Assumption Test}

This study has passed the classical assumption test. The result of normality with the Kolmogorov-Smirnov Test obtained probability score $0.410>0.05$. To test multicolinearity the tolerance value produced $>0.1$ and $\mathrm{VIF}<10$. For $\mathrm{D}-\mathrm{W}$ values obtained autocorrelation test statistic of 1.920. With $\mathrm{n}=175, \mathrm{k}=14$, and a significance level $(\alpha)$ of 5 percent, then the value of $\mathrm{dL}=1.621, \mathrm{dU}=$ 1.919, thus: $(4-\mathrm{dU})=4$ to $1.919=2.081$ and $(4-\mathrm{dL})=$ 4 to $1.621=2.390$. So we can conclude $\mathrm{D}-\mathrm{W}_{\text {statistic }}$ value of 1.920 is in the reception area of $\mathrm{H}_{0}$. To test heteroscedasticity using Glejser seen that the probability value $>0.05$. This means that models are estimated to be free of heteroscedasticity.

\section{Multiple Linear Regression Analysis Test}

Based on Table 2, we get the following multiple regression equation:

$$
\begin{aligned}
\mathrm{DA}= & 5,346+3,712 \mathrm{Lev}+0,00000255 \mathrm{FCF}+0,016 \mathrm{KM} \\
& +0,004 \mathrm{KepIns}+1,018 \mathrm{DKI}+6,274 \mathrm{KA}+(- \\
& \left.0,011 \mathrm{Lev}^{*} \mathrm{KM}\right)+\left(-0,000000212 \mathrm{FCF}^{*} \mathrm{KM}\right)+ \\
& 0,002 \mathrm{Lev}^{*} \mathrm{KepIns}+\left(-0,00000000935 \mathrm{FCF}^{*}\right. \\
& \text { KepIns })+\left(-1,681 \mathrm{Lev}{ }^{*} \mathrm{DKI}\right)+(-0,00000163 \\
& \mathrm{FCF} \mathrm{DKI})+\left(-0,700 \mathrm{Lev}^{*} \mathrm{KA}\right)+0,000000896 \\
& \mathrm{FCF}^{*} \mathrm{KA}
\end{aligned}
$$

\begin{tabular}{|c|c|c|c|c|c|}
\hline & $\mathbf{N}$ & Minimum & Maximum & Mean & Std. Deviation \\
\hline$\overline{\mathrm{DA}}$ & 175 & 5.303 & 18.253 & 13.45479 & 1.834179 \\
\hline Lev & 175 & 0.00025 & 3.60407 & 0.5151495 & 0.43929175 \\
\hline FCF & 175 & $-9 E+007$ & 8378927 & -1382454 & 7328208.228 \\
\hline KM & 175 & 0.000004 & 180.3000 & 3.878133 & 23.8624562 \\
\hline KepIns & 175 & 0.0000 & 693.7000 & 14.685274 & 91.8473769 \\
\hline DKI & 175 & 0.200 & 0.750 & 0.36825 & 0.103367 \\
\hline KA & 175 & 1 & 1 & 1.00 & 0.000 \\
\hline Valid N (listwise) & 175 & & & & \\
\hline
\end{tabular}

Table 1. Descriptive Analysis 


\section{Jurnal Keuangan dan Perbankan | KEUANGAN}

Vol. 21, No. 3, Juli 2017: 412- 424

The results of multiple regression equation indicate that the leverage has a positive effect on earnings management, as shown by the significant value of 0.000 less than 0.05 ( $\alpha=5$ percent) and the regression coefficient of 3.712. Free cash flow positive effects on earnings management, as shown by the significant value of 0.000 less than $0.05(\alpha=5$ percent) and the regression coefficient 0.00000255 . Managerial ownership negatively affects the relationship between leverage and earnings management, this is demonstrated by the significant value of 0.000 less than 0.05 ( $\alpha=5$ percent) and the regression coefficient -0.011 .

Managerial ownership negative effect on the relationship between free cash flow and earnings management, this is indicated by a significance value of 0.000 smaller than 0.05 ( $\alpha=5$ percent) and regression coefficient of -0.000000212 . Institutional ownership does not affect the relationship leverage and earnings management, this is indicated with a significance value of 0.653 is greater than 0.05 ( $\alpha=5$ percent) and koefisien regression of 0.002 . Institutional ownership affects negatively on the relationship of free cash flow and earnings management, as shown by the significant value of 0.015 is less than 0.05 ( $\alpha=5$ percent) and the regression coefficient of -0.00000000935 .

Independent board negatively affect leverage and earnings management relations, as shown by the significant value of 0.048 is less than 0.05 ( $\alpha=5$ percent) and the regression coefficient of 1.681. Independent board does not affect the relationship of free cash flow and earnings management, this is indicated with a significance of 0.371 use values greater than $0.05(\alpha=5$ percent) and the regression coefficient -0.00000163 .

The audit committee negatively affect leverage and earnings management relations, as shown by the significant value of 0.034 is less than 0.05 ( $\alpha=5$ percent) and the regression coefficient of 0.700 . The audit committee does not affect the relationship of free cash flow and earnings management, as shown by the significant value of 0.141 is greater than 0.05 ( $\alpha=5$ percent) and the regression coefficient of 0.000000896 .

Table 2. Multiple Linear Regression Analysis Test

\begin{tabular}{lrrr}
\hline \multicolumn{1}{c}{ Variabel } & Coefficien Regression & Standard Error & Sig. \\
\hline Constants & 5.346 & 2.016 & 0.009 \\
Lev & 3.712 & 0.298 & 0.000 \\
FCF & 0.00000255 & 0.000 & 0.000 \\
KM & 0.016 & 0.002 & 0.000 \\
KepIns & 0.004 & 0.011 & 0.710 \\
DKI & 1.018 & 0.945 & 0.283 \\
KA & 6.274 & 2.052 & 0.003 \\
Lev*KM & -0.011 & 0.000 \\
FCF*KM & -0.000000212 & 0.001 & 0.000 \\
Lev*KepIns & 0.002 & 0.000 & 0.653 \\
FCF*KepIns & -0.00000000935 & 0.005 & 0.015 \\
Lev*DKI & -1.681 & 0.000 & 0.048 \\
FCF*DKI & -0.00000163 & 0.901 & 0.371 \\
Lev ${ }^{*}$ KA & -0.700 & 0.000 & 0.034 \\
FCF*KA & 0.000000896 & 0.328 & 0.141 \\
F-statistics: 203.561. Sig=0.000. & & 0.000 & \\
DW-statistics:1.920 & & & \\
N=175 & & & \\
\hline
\end{tabular}




\section{The Role of Corporate Governance as a Leverage Moderating and Free Cash Flow on Earnings Management}

Reni Yendrawati, Erin Febriana Asy'ari

\section{F Test}

$F$ test results indicate calculated $F$ value of 34.031. Obtained by the Sig= 0.000 . Value shows the error rate to be borne by the researcher if the model is said to be good. Since the significant value of $\mathrm{F}$ is 0.000 it can be concluded that the error rate is very small. Little significant value $\mathrm{F}$ indicates the existing model is a good model and fit for use.

\section{DISCUSSION}

The results of multiple linear regression showed that the leverage effect positive significantly to earnings management. It means that increasing leverage, then also increase the earnings management. Because debt (leverage) is an agreement between the company as a debtor by creditors. In agreement debt, there is the interest of the company to be assessed positively by the lenders in terms of ability to pay the debts of her. There is a possibility that the contract agreements of debt triggered management to increase profits with the aim of showing the positive performance on the lender because the performance is considered stable so that companies obtain injections funds. The usual management measures are income smoothing to obtain a stable impression by the creditors (Zakaria, Sanusi, \& Mohamed, 2015). The results support the research that has been done by Zamri, Rahman, \& Isa (2013) and conducted by Lee (2013) who found results that the leverage effect on the actions of earnings management.

Free cash flow impact positively significantly to earnings management. This means that increasing free cash flow, then the earnings management will also be increasing. Because with their free cash flow will encourage managers to invest. As a result, companies with high free cash flow is accompanied by low growth opportunities will tend to continue to invest in projects with negative NPV, which may be beneficial for managers, either in cash or in exchange for something else, it will degrade the performance of the company. Furthermore, in an attempt to cover up the company's performance, the manager will act earnings management to increase profits (Fanani, 2014).

Managerial ownership significant negative effect on the relationship between leverage and earnings management. This means that the managerial ownership capable to reduce leverage and these earnings. This management explained that if the managerial ownership over securities companies can equate the interests of management with external parties. Increasing ownership by management, will lead the management of prudence in the use of debt and avoid opportunistic behavior because they bear the consequences of his actions. So that managerial ownership may reduce the willingness of management to follow the earnings management.

Managerial ownership significant negative effect on the relationship between free cash flow to earnings management. This means that managerial ownership is able to reduce the free cash flow relationship with earnings management. Due to a managerial ownership over securities companies can equate interest with an external management company, where such interest is the desire to get the result of the division of dividends received from free cash flow. This means that the presence of managerial ownership, the relationship between free cash flow to earnings management can be reduced. Because if the high managerial ownership then stock returns will also be high, so that the management does not want to commit acts of earnings management. Because management does not only serve as the manager of the company, but also as shareholders who desire high stock returns. The results of this study support the research Naftalia (2013) concluded that management ownership in the shares of companies seen to align the potential divergence of interests between shareholders with management. So that the problems the agency arising from their free 


\section{Jurnal Keuangan dan Perbankan | KEUANGAN}

Vol. 21, No. 3, Juli 2017: 412- 424

cash flow of a company is assumed to be lost if a manager to act at once as an owner.

Institutional ownership does not affect the relationship between leverage and earnings management. This means that institutional ownership has no effect in reducing leverage and profit. It means that if there institutionally ownership, institutional ownership can not moderate the relationship between leverage and earnings management. Due according Kusumaningtyas (2012) the purpose of institutional ownership as a temporary owner who is more focused on current earnings, while the focus of leverage is long term. So it can be concluded that institutional ownership is not focused on management decisions related to the high degree of leverage can lead to earnings management.

Institutional ownership significant negative effect on the relationship between free cash flow with earnings management. This means that the ownership of institutional able to reduce free cash flow relationship with profit. This is because managers tend to pursue personal interests, using free cash flow to pay the salaries, allowances and bonus on their own and use the free cash flow available for investment alternatives without selective in profitable projects, which would benefit projects that do not decrease the value of the company so that the manager will tend to follow the earnings management to cover up the lack of their performance. With the improvement of the monitoring mechanism by the managers of institutional investors will be more selective in their choice of investment alternatives and not just acting to pursue personal gain but to enhance corporate value and shareholder wealth. It can be concluded that the existence of institutional ownership in the company can prevent earnings management due to the use of free cash flow is not effective.

Independent Board of Commissioner significant negative effect on the relationship between leverage and earnings management. This means that independent board is able to reduce leverage and profit. These management this means that the more the number of independent board then increased surveillance measures in order to reduce earnings management action. Due to the presence of independent board oversight function, where its function is to monitor outcomes keuanganan statements, the management can not perform opportunistic in the use of leverage can lead to acts of management earnings.

Independent Board of Commissioner has no effect on the relationship between free cash flow to earnings management. This means that the independent board was not able to reduce the free cash flow relationship with earnings management. This means in terms of the presence or absence of independent board can not afford meminimilasir profit management action caused by free cash flow. Due to one of the functions of the independent board is as protective rights of minority shareholders, thus demanding the management to pay dividends on free cash flow which causes management actions earnings management by lowering the profit so that the profits be little to be shared and this includes management actions profit.

Audit committee has significantly negative effect on the relationship between leverage and earnings management. This means the audit committee able to reduce leverage and earnings management. That is because the committee that serves as a supervisor audit management in preparing the financial statements, the audit committee ensures the financial statements have been prepared based on PSAK. High leverage is a result of inefficiency in the management prepared a report on the financial causes the company will go bankrupt because the company can not pay debt Long-term assets owned. So that management can not perform earnings management practices on leverage as overseen by the audit committee.

Audit Committee of the audit does not affect the relationship between free cash flow to 
earnings management. This means audit committee is not able to reduce the free cash flow relationship with the earnings management. This means that if there is an audit committee, audit committee can not moderate the relationship between free cash flow to earnings management. Due to the existence of an audit committee that serves as a supervisor of the financial statements, free cash flow is used by management in making investments rated as good by the audit committee for the sustainability of the company. So that will happen in lowering their profit earnings management to distribute free cash flow as dividends to shareholders and management can make use of free cash flow in investment activity.

\section{CONCLUSION AND SUGGESTIONS}

\section{Conclusion}

This study aimed to analyze the effect of leverage, free cash flow to earnings management as well as analyze the impact of corporate governance on the relationship of leverage and free cash flow to earnings management.

Result of study showed that leverage and free cash flow positive significant effect on earnings management action. If leverage and free cash flow increases, so the action of earnings management increases. Managerial ownership moderating leverage relationships and free cash flow to earnings management proved significant. With increasing managerial ownership, it will weaken the relationship of leverage and free cash flow to earnings management.

Institutional ownership moderating leverage and earnings management relations proved to be significant. Increase or decrease in institutional ownership does not affect leverage relationships with earnings management. Institutional ownership that moderate the relationship of free cash flow and earnings management proved significant. The increasing institutional ownership will further weaken the relationship of free cash flow to earnings management. Independent board that moderate the relationship leverage and free cash flow with management earnings proved significant. With increasing commissioners of independent will weak relationships leverage and free cash flow to earnings management. The audit committee moderating leverage and earnings management relations proved significant. With the increase of the audit committee will weaken the relationship leverage with earnings management. The audit committee which moderates the relationship of free cash flow and earnings management proved to be insignificant. Increases or decrease number of audit committee is not going to affect the relationship of free cash flow to earnings management.

\section{Suggestions}

This study has some limitations that may affect the results of research that want to achieved, that this study only took samples from the manufacturing companies listed in Indonesia Stock Exchange by purposive sampling and based on the theory that agency theory, where there are theories another explains the motivation of managers in managing earnings.

As for suggestions that could be given related to this research for further research is expected to use a broader sampling as companies overall are listed in the Indonesia Stock Exchange or other exchanges so that research results can be generalized and is expected to add to the theory other basis to be know the motivation of managers in making profit management, where earnings management practices can be explained not only of agency theory, but there is another theory that can explain earnings management practices undertaken by corporate managers. For companies should better understand the role of the practice of corporate governance on earnings management due to the influence of the level of debt (leverage) and free cash flow activities. 


\section{Jurnal Keuangan dan Perbankan | KEUANGAN}

Vol. 21, No. 3, Juli 2017: 412- 424

\section{REFERENCES}

Agustia, D. 2013. Pengaruh Faktor Good Corporate Governance, Free Cash Flow, dan Leverage terhadap Manajemen Laba. Jurnal Akuntansi dan Keuangan, 15(1): 27-42.

Arieska, M. \& Gunawan. 2011. Pengaruh Aliran Kas Bebas dan Keputusan Pendanaan terhadap Nilai Pemegang Saham dengan Set Kesempatan Investasi dan Dividen Sebagai Variabel Moderasi. Jurnal Akuntansi dan Keuangan, 13(1): 13-23.

Brigham, E.F. \& Houston, J.F. 2010. Dasar-Dasar Manajemen Keuangan Buku 1. Jakarta: Salemba Empat.

Dechow, P.M., Sloan, R.G., \& Sweeney, A.P. 1995. Detecting Earning Management. The Accounting Review, 70(2): 193-225.

Fanani, Z. 2014. Karakteristik Perusahaan dan Corporate Governance terhadap Manajemen Laba: Studi Analisis Meta. Jurnal Keuangan dan Perbankan, 18(2): 181-200.

Gunawan, I.K., Darmawan, N.A.S., \& Purnamawati, I.G.A. 2015. Pengaruh Ukuran Perusahaan, Profitabilitas, dan Leverage terhadap Manajemen Laba pada Perusahaan Manufaktur yang Terdaftar di Bursa Efek Indonesia (BEI). E-Journal S1 Ak Universitas Pendidikan Ganesha Jurusan Akuntansi Program S1, 3(1): 1-10.

Ikatan Akuntansi Indonesia (IAI) 2007. Standar Akuntansi Keuangan. Jakarta: Salemba Empat.

Kono, D.F.P. 2013. Pengaruh Arus Kas Bebas, Ukuran KAP, Spesialisasi Industri KAP, Audit Tenur, dan Independensi Auditor terhadap Manajemen Laba (Studi Empiris pada Perusahaan Manufaktur yang Terdaftar di Bursa Efek Indonesia Tahun 20092011). Thesis. Diponegoro University.
Kristiani, K.E., Sulindawati, N.L.G.E., \& Herawati, N.T. 2014. Pengaruh Mekanisme Corporate Governance dan Ukuran Perusahaan. E-Journal S1 Ak Universitas Pendidikan Ganesha Jurusan Akuntansi Program S1, 2(1): 1-12.

Kusumaningtyas, M. 2012. Pengaruh Independensi Komite Audit dan Kepemilikan Institusional terhadap Manajemen Laba. Prestasi, 9(1): 41-61.

Lee, R. 2013. Pengaruh Leverage, Kepemilikan Institusional, Ukuran dan Nilai Perusahaan terhadap Tindakan Manajemen Laba. Jurnal Wira Ekonomi Mikroskil, 3(1): 41-50.

Naftalia, V.C. 2013. Pengaruh Leverage terhadap Manajemen Laba dengan Corporate Governance sebagai Variabel Pemoderasi. Diponegoro Journal of Accounting, 2(3): 1-11.

Pambudi, J.E. \& Sumantri, F.A. 2014. Kualitas Audit, Ukuran Perusahaan, dan Leverage terhadap Manajemen Laba. Simposium Nasional Akuntansi XVII Mataram.

Ridwan, M. \& Gunardi, A. 2013. Peran Mekanisme Corporate Governance sebagai Pemoderasi Praktik Earning Management terhadap Nilai Perusahaan. Trikonomika, 12(1), 49-60.

Zakaria, N.B., Sanusi, Z.M., \& Mohamed, I.S. 2015. The Effect of Free Cash Flow, Dividend, and Leverage to Earnings Management Evidence from Malaysia. Research Gate.

Zamri, N., Rahman, R.A., \& Isa, N.S.M. 2013. The Impact of Leverage on Real Earnings Management. Procedia Economics and Finance, 7: 86-95. 